\title{
Effects of sward structure upon herbage intake by grazing dairy cows
}

\author{
L Astigarraga 2, JL Peyraud 1 \\ IINRA, Station de Recherches sur la Vache Laitière, 35590 Saint-Gilles, France; \\ 2Facultad de Agronomia de la Universidad de la República, Uruguay
}

This report describes the consequences upon herbage organic matter intake (HOMI) and ruminal digestion of large difference between periods in sward structure during a short term experiment which originally aimed at studying the effect of nitrogen fertilization and protein supplementation (Astigarraga et al, 1994, Ann Zootech, 43, 292).

The experiment was designed as a $3 \times 3$ latin square using 9 fistulated dairy cows during three periods of 14 days, from 12 May to 22 June 1992. The sward was strip-grazed at a high daily herbage allowance of $28 \mathrm{~kg} \mathrm{OM} / \mathrm{cow}$. HOMl was estimated as described Peyraud et al (this issue). Grazing time (GT), rumination time (RT), extended tiller height (ETH) and leaf sheath height (LSH) were recorded. Particle mean retention time (MRT) and cellulolytic activity (estimated by the rate of DM disappearance of soyabean hulls) were measured.

During the first two periods, herbage mass (HM) and ETH were similar, but LSH was much higher on $\mathrm{P} 2(\mathrm{P}<0.001)$. The reduction in HOMl observed on P2 ( $P<0.001)$ might be related to this greater sheath proportion in $\mathrm{HM}$ that could have reduced the prehensibility of the sward. This latter is supported by the lower rate of ingestion on that period $(P<0.01)$. The increase in NDF content $(P<0.01)$ associated to the high leaf sheath fraction of the pasture led to a higher unitary RT on $\mathrm{P} 2(\mathrm{P}<0.001)$. Additionally, the decrease in NDF digestibility $(P<0.001)$ reflected a variation in the quality of the fiber since both cellulolytic activity and MRT did not varied significantly between the 2 periods. In P3, flower heads represented $63 \%$ of the stems in the canopy. $\mathrm{HM}(\mathrm{P}<0.003)$ and ETH $(P<0.001)$ were lower than for the two first periods, NDF content was similar to $\mathrm{P} 2$ but $\mathrm{CP}$ decreased $(P<0.003)$. Nonetheless neither HOMI nor the rate of ingestion were modified between $P 1$ and $P 3$. Thus, the early stage of heading did not affect HOMI, likely because of the higher DM content of the herbage on $\mathrm{P} 3$ $(15 \%, 15 \%$ and $24 \%$ for $\mathrm{P} 1, \mathrm{P} 2$ and $\mathrm{P} 3$, respectively) $(P<0.001)$. Though, Digestible OM intake was lowered on P3 $(P<0.001)$, associated to a reduced cellulolytic activity $(\mathrm{P}<0.001)$ which might be related to the greater intake of soluble carbohydrates $(3.0,2.6$ and $4.4 \mathrm{~kg} / \mathrm{d}$ for $\mathrm{P} 1, \mathrm{P} 2$ and $\mathrm{P} 3$, respectively) $(P<0.001)$ and to the lower ammonia level in rumen fluid (169, 169 and $64 \mathrm{mg} / \mathrm{l}$ for $\mathrm{P} 1, \mathrm{P} 2$ and $P 3$, respectively) $(P<0.001)$.

This data pointed out the detrimental effect of a high LSH on herbage prehensibility and HOMI. On the other hand, the appearance of the flower horizon at an early stage, might not affect HOMl at grazing.

$\begin{array}{lcccc} & \text { P1 } & \text { P2 } & \text { P3 } & \text { SEM } \\ \text { HM (t OM/ha) } & 4.55 & 4.90 & 3.33 & 0.304 \\ \text { ETH (cm) } & 57 & 59 & 39 & 1.5 \\ \text { LSH (\% ETH) } & 0.44 & 0.69 & 0.67 & 0.028 \\ \text { NDF (\% OM) } & 53 & 59 & 54 & 1.5 \\ \text { CP (\% OM) } & 15 & 14 & 11 & 0.8 \\ \text { HOMl (kg/d) } & 17.2 & 15.1 & 17.0 & 0.86 \\ \text { GT (min/d) } & 502 & 537 & 484 & 46.6 \\ \text { RT (min/kg OM) } & 26 & 32 & 35 & 2.2 \\ \text { OM digestibility } & 0.833 & 0.784 & 0.760 & 0.0051 \\ \text { NDF digestibility } & 0.809 & 0.737 & 0.683 & 0.0108 \\ \text { MRT (h) } & 23 & 21 & 19 & 1.5 \\ \text { cellulolytic activity } & 0.557 & 0.549 & 0.509 & 0.0180\end{array}$

